\title{
VALUE CHAIN GOVERNANCE FOR SMOKED FISH PRODUCTS IN THE NORTH COAST OF CENTRAL JAVA
}

\section{Indrajit Wicaksana*1, Rita Nurmalina*), and Suprehatin****)}

*) Department of Agribusiness, Faculty of Economics and Management, IPB University Jl. Agatis, Campus of IPB Darmaga Bogor 16680, Indonesia

**) Center for Agriculture and Rural Development Studies, IPB University

Jl. Raya Pajajaran, Baranangsiang Campus IPB Bogor 16129, Indonesia

\begin{abstract}
The seafood and aquaculture industry in Indonesia is much less vertically coordinated. However, there are trends towards coordination in fishery value chains through processing and distribution to retail and food service customers. This study aims to examine the governance of the smoked fish value chains in the North Coast of Central Java. The study used the survey data of 52 actors along the smoked fish value chains in the North Coast of Central Java, including fisherman in Demak and Rembang regencies, various types of middleman, processor, and retailers in Semarang. The data was analyzed using value chain mapping and governance analyses. The results showed that the actors involved in the smoked fish value chains consist of fishermen, wholesalers, collectors, processors, retailers, food stalls, and restaurants. Each actor has different activities in their role to add value to differentiate smoked fish products. The results also showed that the types of value chain governance of smoke fish in the North Coast of Central Java leads to relational governance with the complex and interdependent transactions.
\end{abstract}

Keywords: aquaculture, coordination, fisherman, fishery products, relational

\begin{abstract}
Abstrak: Industri perikanan di Indonesia masih menghadapi koordinasi vertical yang rendah.. Meskipun demikian, saat ini sudah ada kecenderungan terbangunnya koordinasi dalam suatu rantai nilai perikanan melalui proses pengolahan dan distribusi kepada konsumen ritel dan jasa makanan. Penelitian ini bertujuan untuk menganalisis tata kelola rantai nilai produk ikan asap di Pantai Utara Jawa Tengah. Penelitian ini menggunakan data dari survei terhadap 52 pelaku di sepanjang rantai nilai produk ikan asap di Pantai Utara Jawa Tengah termasuk nelayan di Kabupaten Demak dan Rembang, pedagang perantara, pengolah, dan pedagang pengecer di Semarang. Analisis data menggunakan analisis pemetaan dan tata kelola rantai nilai. Hasil penelitian menunjukan bahwa para pelaku rantai nilai ikan asap terdiri dari nelayan, pedagang besar, pedagang pengumpul, pengolah, pedagang pengecer, warung makan, dan restoran. Setiap pelaku memiliki aktivitas berbeda dalam perannya untuk menciptakan rantai nilai produk ikan asap. Hasil penelitian juga menunjukan bahwa tipe tata kelola rantai nilai ikan asap di Pantai Utara Jawa Tengah tergolong ke dalam tata kelola relasional dimana transaksi bersifat kompleks dan saling bergantung.
\end{abstract}

Kata kunci: budidaya perikanan, koordinasi, nelayan, produk perikanan, relasional

\footnotetext{
${ }^{1}$ Corresponding author:
}

Email:wicaksana1329@gmail.com 


\section{INTRODUCTION}

The value of Indonesian fisheries production in 2017 showed a high number, which was Rp384,5 trillion. The national fisheries production value came from marine fisheries, which reached $51,3 \%$ or Rp197,3 trillion, while the remaining $(48,7 \%)$ came from aquaculture (KKP, 2019). The role of the marine fisheries and aquaculture is continuing to grow to the Indonesian economy, including in the community income and job creation. However, this contribution can be optimized if these fisheries products are also processed and produced into higher value-added products to fulfill the consumer demand as the case in the marine fisheries sector in Kenya (Theuri et al. 2014).

One of the main reasons to develop seafood and aquaculture processing industries is the nature of fisheries products that are easily damaged or deteriorated if it is not processed. Currently, the processing of fishery products in Indonesia has been dominated by frozen fish $(55,42 \%)$ and fresh fish $(13,06 \%)$, then followed by smoked fish $(9,58 \%)$, canned fish $(5,69 \%)$, and other fish processing (16,25\%) (KKP, 2018). Compared to fresh fish and frozen fish, fishery products can be produced into higher value-added products such as smoked fish, canned fish, and other processed fish.

Currently, smoked fish industry in Indonesia is continuously growing. Both small and medium enterprises (SMEs) and large enterprises are playing a role as it is relatively easy to process fishery products into higher value smoked fish. Generally, Indonesian SMEs have applied traditional preservation methods using simple equipment to run their smoked fish business. However, this conventional method can preserve fish and improve the quality of fish by adding its value to smoked fish products. One of the unique values of smoked fish is its better taste than frozen fish (Alhassan, 2012). Commonly, smoked fish products are used by communities or restaurants to make Javanese delicious culinary dishes known as mangut (Dzaki and Sugiri, 2015).

In the development stages, smoked fish products are not only processed and sold directly to the consumers or retailers, but also packaged in more modern packaging, which is vacuum packaging. The vacuum packaging makes smoked fish last longer and protect the product safer for consumption (Swastawati et al. 2017). The vacuum packaging has been able to add higher value of smoked fish and make it easier to market it. For example, compared to the smoked fish without vacuum packaging, the price of smoked fish with vacuum packaging is two times higher, which is Rp140.000 and Rp60.000 per kg respectively (Arsiwi et al. 2018). Furthermore, the vacuumed smoked fish products also provide opportunities to expand markets, both national and global markets. However, expanding markets and meeting changing consumer demand for smoked fish products need to maintain greater domestic added value (Ahmad et al. 2018) and increase investment at the smoked fish value chain development (Yusri et al. 2012).

Developing smoked fish value chains in Indonesia involves many actors from fisherman to retailers and consumers across regions. However, like the nature of Indonesian seafood and aquaculture industry, the smoked fish value chains are much less vertically coordinated. It is a big challenge in developing sustainable smoked fish value chains in Indonesia to contribute more to the national economy. Developing sustainable smoked fish value chains can be further examined using value chain governance (Hastings et al. 2016). Therefore, this study aims to examine the governance of the smoked fish value chains in the North Coast of Central Java. This study uses the North Coast of Central Java context as there is trend towards coordination in the smoked fish value chains in regions including fisherman, middleman, processors and consumers across regions such as fisherman in Demak and Rembang regencies, SMEs in Demak regency and restaurants in Semarang.

In this study, governance focuses on the power relations that exist between value chain actors who determine how financial, material, and human resources are allocated and moved within a chain (Clay and Feeney, 2019). Relations and cooperation that exists between the actors show that there is a chain formed both formally and informally to cooperate and coordinate in delivering and producing valuable products into the hands of consumers. Formal cooperation can be demonstrated by the existence of institutional roles such as cooperatives of fish cultivation group. Previous research shows that fishing cooperatives have different roles, such as providing access to the market (Yulisti and Triyani, 2012), access to capital and production facilities (Yusuf et al. 2014). On the other hand, informal governance has more complex conditions than formal governance or written contractual relations (Mishra 
and Dey 2018). This may be due to the existence of several value chain actors who tend to obtain partial or incomplete information (asymmetric information), including price information. Therefore, it is necessary to know the types of governance of the smoked value chains as a picture of the relationship and cooperation between each actor to create the value of smoked fish products needed by consumers.

\section{METHODS}

The study was conducted in the North Coast regions of Central Java. However, as a starting point, the study started from the smoked fish clusters consisting of SMEs processors in Wonosari Village, Demak Regency, Central Java, namely KUB Asap Indah. This group is one of the national pilot projects for the smoked fish products of the Ministry of Maritime Affairs and Fisheries. The location selection was done intentionally (purposive) because KUB Asap Indah is one of the biggest smoked fish centers in the Demak Regency, which has implemented a centralized fish smoke processing. The KUB Asap Indah is a cooperative with members consist of SMEs of smoked fish processors. This study used primary data obtained from field study activities through questionnaires and interviews with actors who play an important role in the smoked fish value chains. The data collection was conducted during February 2020. The study also used secondary data obtained from the Central Statistics Agency, the Directorate General of Strengthening Competitiveness of Marine Products and Fisheries KKP-RI, Demak Regency's Maritime and Fisheries Service, and various data from other supporting literature.

Sampling was done by snowball and purposive sampling techniques. Snowball sampling is a technique for determining a sample that is small in number and then enlarged (Sugiyono, 2014). Meanwhile, purposive sampling is a sampling technique with certain considerations (Sugiyono, 2014). Snowball sampling in this study involved the process of identifying samples in a network that takes place continuously by considering that each actor is an individual or group involved in the flow of activities along the value chain. The purposive sampling in this study was used to determine the number of processors involved in the value chain. Both of these techniques are also used by Luhur and Yusuf (2017) and Puspito et al. (2016) in their research on agribusiness value chains. Respondents in this study were 52 actors consisting of five fishermen both in Demak and Rembang regencies, four traders, 30 processors, ten retailers, two food stall owners, and one restaurant owner. Due to time constraints and pandemic Covid-19, we could not interview the food stalls and restaurants outside Demak regency, such as in Semarang and other regencies. The collected data was then processed using descriptive analysis, namely, value chain analysis, which consisted of value chain mapping and governance analyses.

\section{Value Chain Mapping Analysis}

The process of analyzing value chain governance is preceded by mapping analysis. The mapping process is carried out to obtain a general picture of the overall activity of the actors in creating the value of a product. Value chain mapping analysis includes qualitative and quantitative approaches. No fixed rules are governing which approach is better, but there are recommendations for a qualitative approach first then followed by a quantitative approach (Hellin and Meijer, 2006). The main problem in mapping value chains is how to get numbers and values as a variable to be examined (Kaplinsky and Morris, 2002). Therefore, data collection starts with each actor who acts as a respondent in the value chain.

The process of mapping the value chain consists of ten stages: (1) determining the core process carried out by each actor, (2) identifying each actor involved in the core process, (3) mapping the value-added flow of a product in the value chain, (4) mapping the flow of knowledge and information of a product, (5) mapping the volume of products, the number of actors, and the number of jobs, (6) mapping the flow of geography related to the product transfer process, (7) mapping the flow of product value at various levels, (8) mapping the relationships and linkages of each actor related to the transaction, (9) mapping of obstacles and potential solutions, and (10) making a matrix of value chain maps (ACIAR, 2012).

\section{Value Chain Governance Analysis}

Governance in the value chain analysis is carried out to identify various rules that are formed among actors, such as the system of coordination, regulation, and management of all activities in the value chain. Governance refers to the structure of relationships and the mechanism of coordination between each 
actor. Analysis of value chain governance can be used as a method for developing relationships along the value chain, such as collaboration activities and close cooperation (Hastings et al. 2016).

Based on Gereffi and Humphrey (2005), there are five types of value chain governance, namely market, modular, relational, captive, and hierarchy (Figure 1). The process of determining the type of governance can be identified by using the main framework consisting of complexity, codify, and capability. This main framework is an indicator variable that is used to determine the type of value chain governance by determining the level of the indicator's high and low levels (Albuloushi, 2018). Determinants of governance type in Table 1.

First, complexity in managing the value chain is identified as the complexity of the transfer of information and knowledge needed to maintain ongoing transactions, especially those related to product and process specifications. Second, codify includes several ways to make transactions run efficiently, such as forming formulations, knowledge, passwords, codes, or information as outlined in the format of reports, memos, or policies to simplify the process of information transfer and coordination between actors in the value chain. This codification process can be saved in the form of documents or software.

Third, the capability is conceptualized as the capability of the supplier, which in this case is strongly influenced by the perspective and criteria of the buyer, so that a relationship is created in the form of a transaction. Supplier capabilities include supplier skills and abilities in meeting long-term or short-term buyer desires.

\section{RESULTS}

The initial stage in explaining the value chain is to identify the mapping of several indicators related to the value chain, which include the number of actors involved, the core processes or main activities of each actor, and the percentage of product volume. Each of these indicators can provide an initial overview to be able to carry out the next analysis stage in the form of governance analysis.

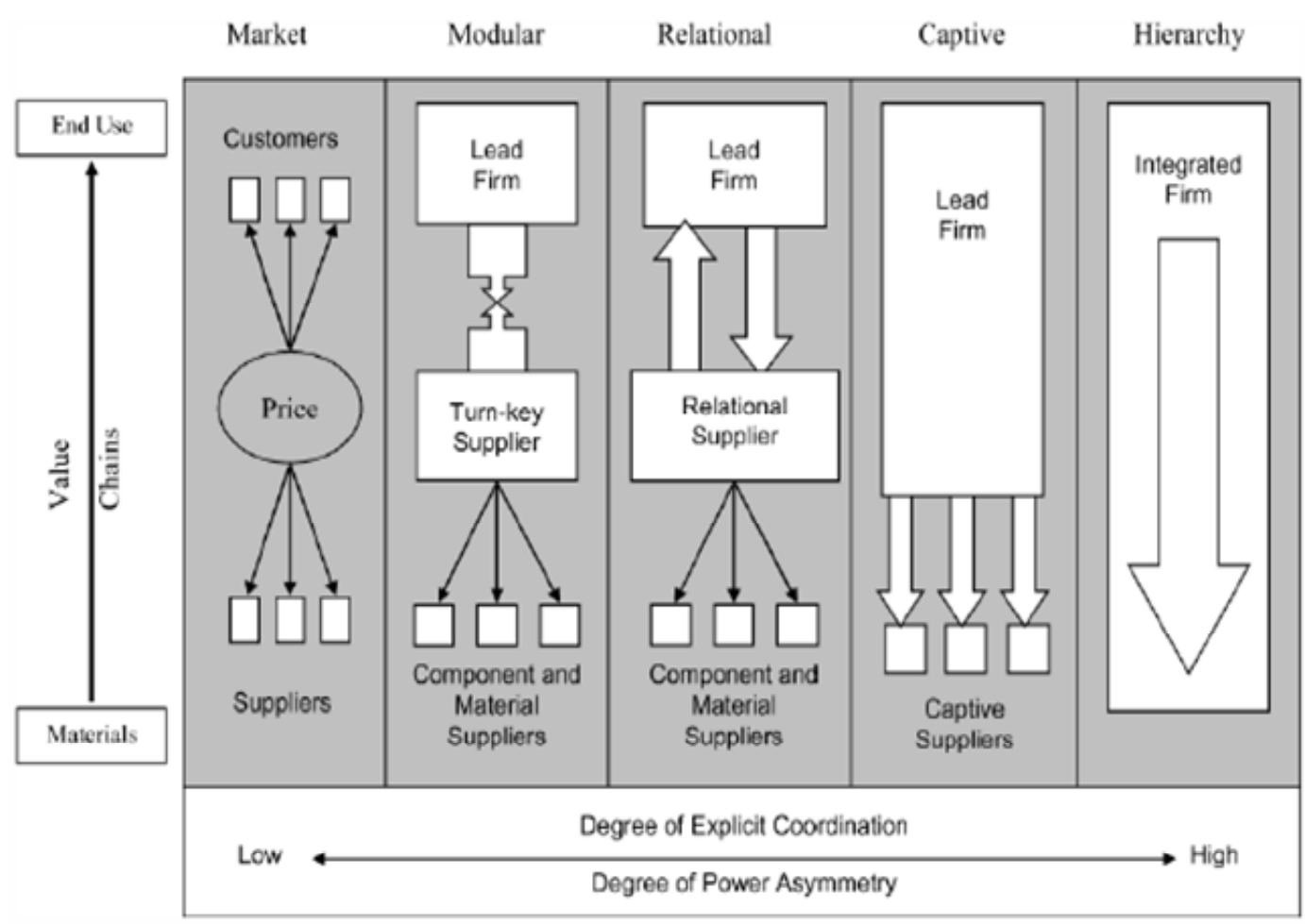

Figure 1. Types of governance in the value chain (Gereffi dan Humphrey, 2005) 


\section{The Smoked Fish Value Chain Actors}

KUB Asap Indah has 76 processing groups which is capable of producing smoked fish with an average production value of up to nine tons per day or $120 \mathrm{~kg}$ per day for each processor. The types of fish smoked that mostly processed by the processors are manyung, tongkol, and pari. Actors involved in the smoked fish product value chain in Demak Regency include fishermen, wholesalers, middlemen, smoked fish processors, retailers, and food stalls or restaurants. There are five marketing channels formed in the smoked fish value chains in the North Coast of Central Java (Figure 2).

The main smoked fish value chain activities

Overall, each actor in the smoked fish value chain performs main activities according to their capacity (Table 2). Exceptions for fishermen, each actor carries out the same three activities consisting of purchasing, selling, and standardizing products for both fresh fish and smoked fish.

Table 1. Determinants of governance type

\begin{tabular}{lcccc}
\hline Types of governance & Complexity & Codify & Capability & Power Asymmetry \\
\hline Market & Low & High & High & Low \\
Modular & High & High & High & \\
Relational & High & Low & High & $\downarrow$ \\
Captive & High & High & Low & $\downarrow$ \\
Hierarchy & High & Low & Low & High \\
\hline
\end{tabular}

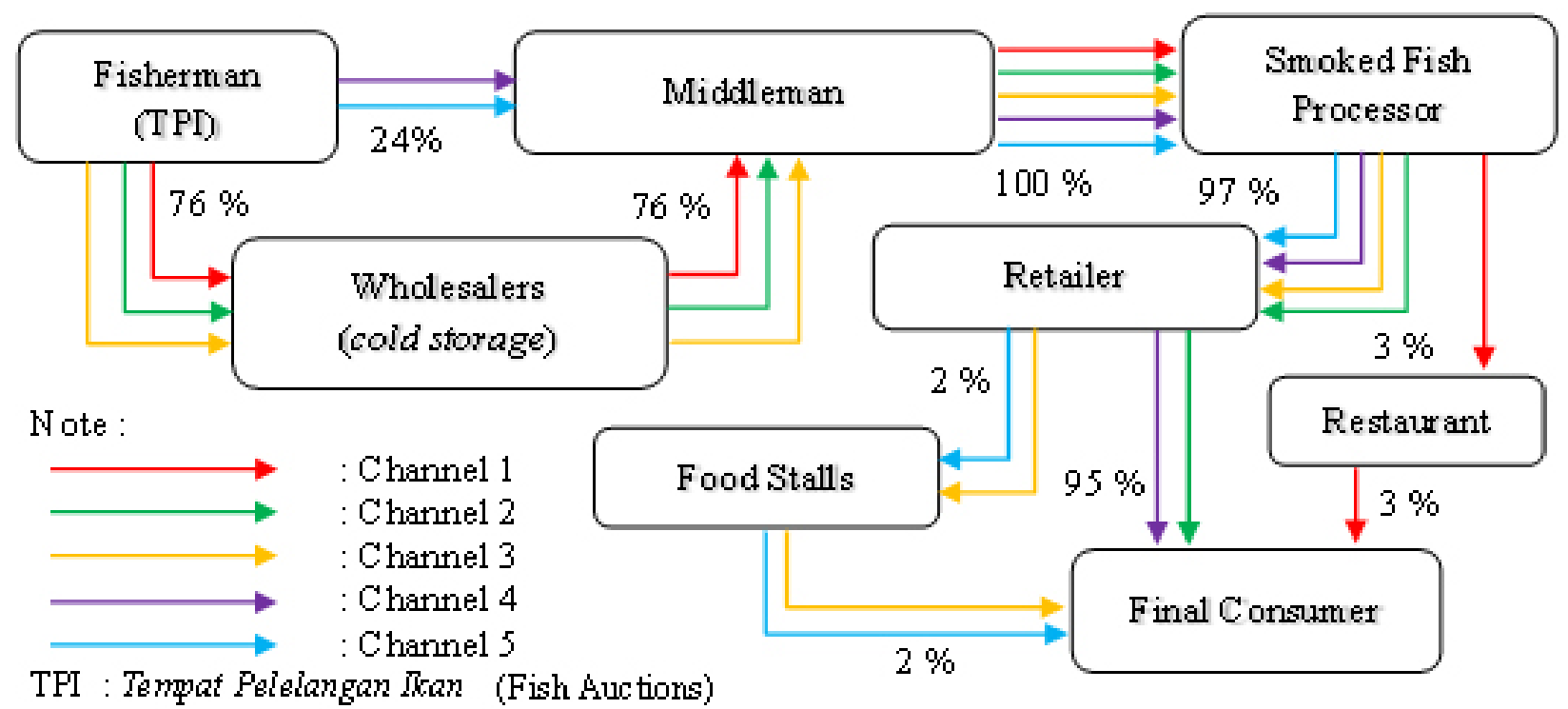

Channel 1: Fishermen - Wholesalers - Middlemen - Processors - Restaurants - Final Consumers

Channel 2: Fishermen - Wholesalers - Middlemen - Processors - Retailers - Final Consumers

Channel 3: Fishermen - Wholesalers - Middlemen - Processors - Retailers - Food Stalls - Final Consumers

Channel 4: Fishermen - Middlemen - Processors - Retailers - Final Consumers

Channel 5: Fishermen - Middlemen - Processors - Retailers - Food Stalls - Final Consumers

Figure 2. The marketing channels formed in the smoked fish value chains in the North Coast of Central Java 
Table 2. The main activities of each actor in smoked fish value chains in the North Coast of Central Java

\begin{tabular}{lccccccc}
\hline \multirow{2}{*}{ Main activities } & \multicolumn{7}{c}{ Value chain actors $^{\mathrm{a}}$} \\
\cline { 2 - 8 } & NLY & PBS & PPL & PLH & PPC & WMK & RST \\
\hline Fish catching & $\sqrt{ }$ & - & - & - & - & - & - \\
Storage & $\sqrt{ }$ & $\sqrt{ }$ & - & - & - & - & $\sqrt{ }$ \\
Processing & - & - & - & $\sqrt{ }$ & - & $\sqrt{ }$ & $\sqrt{ }$ \\
Distributing & - & $\sqrt{ }$ & $\sqrt{ }$ & - & $\sqrt{ }$ & - & - \\
Purchasing & - & $\sqrt{ }$ & $\sqrt{ }$ & $\sqrt{ }$ & $\sqrt{ }$ & $\sqrt{ }$ & $\sqrt{ }$ \\
Selling & $\sqrt{ }$ & $\sqrt{ }$ & $\sqrt{ }$ & $\sqrt{ }$ & $\sqrt{ }$ & $\sqrt{ }$ & $\sqrt{ }$ \\
Standardizing & $\sqrt{ }$ & $\sqrt{ }$ & $\sqrt{ }$ & $\sqrt{ }$ & $\sqrt{ }$ & $\sqrt{ }$ & $\sqrt{ }$ \\
\hline
\end{tabular}

Note: aNLY is fisherman; PBS is wholesaler; PPL is middleman; PLH is processor; PPC is retailer; WMK is food stall; RST is restaurant.

Meanwhile, fishermen only carry out sales and standardization activities. Fishermen do not make purchases because their main activity is fishing. This fisherman's activity is different from Kotni's (2016) research, where fishermen in Andhra Pradesh, India also carry out primary value-added activities such as cleaning, valuing, separating, washing, weighing, cooling, and packing fish.

Each value chain actor has a characteristic in carrying out his main activities such as wholesalers carrying out storage and distribution activities, middleman carrying out distribution activities without storage, processors conducting fish fumigation, and retailers doing the distribution of smoked fish. Specifically for food stalls and restaurants perform the main activity of processing smoked fish into a typical cuisine from Java, namely mangut.

The volume of products in the smoked fish value chains

Large volumes of smoked fish products along the value chain are obtained by determining the average volume of fresh fish raw material usually processed by all processors at the Demak smoked fish center, which is nine tons per day. The volume of products moving from upstream to downstream has decreased due to the process of determining the quality of fresh fish (standardization) and fish waste when processing smoked fish. The analysis process is focused on the types of fish that are widely used as raw materials for smoked fish consisting of manyung, tongkol, and pari.

The initial process starts with fishermen selling most of their catch to brokers. As many as $76 \%$ of fresh fish owned by fishermen is sold to wholesalers to be frozen, then the remaining $24 \%$ in the form of fresh fish is sold to middlemen (Figure 2). Both types of fish, frozen and fresh fish, are all bought by middlemen. This means that as much as $100 \%$ of the raw material for fish obtained by middlemen will be sold to processors at smoked fish centers (Figure 2).

After the smoke fish processing is completed, the processor sells most of the smoked fish products to retailers and sells a small portion to restaurants. Each processor has at least one retailer who has become a permanent distributor to sell its products. This means that the smoked fish center is not only a center for smoked fish processing but also a center for smoked fish sales. About $97 \%$ of the smoked fish are bought by retailers who will then be traded again, and the remaining $3 \%$ will be directly sold to restaurants (Figure 2). The number of smoked fish originating from retailers is as much as $95 \%$ bought by household end consumers (Figure 2). The remaining 2\% is bought by food stalls to be reprocessed into mangut which will then be sold to end consumers (Figure 2).

\section{The Smoked Fish Value Chain Governance Coordination Systems}

The next stage of value chain analysis is the analysis of governance based on the existence of interconnected activities among value chain actors, including the system of coordination, regulations, and certain requirements, and control mechanisms. The coordination system is the basis for the process of collaboration between smoked fish product value chain actors. The coordination formed is only informal or unwritten and is only based on a high level of trust among the actors. This is aligned with research by Trienekens (2011) and Rosales et al. (2017) in the fish product value chain in the Philippines, where most relationships in the value chain are informal, interdependent in the long run, and 
based on trust and commitment. This basis of trust is important as the foundation for creating a strong value chain. Relationships that are established without trust can create weak coordination (ACIAR, 2012). In the smoked fish value chain, the relationship between processors and middlemen, as well as processors and retailers have been strongly intertwined. The smoked fish value chain relationship is based on the principle of kinship based on the existence of cultural or regional origin similarity so that the relationship is stronger than the written agreement. However, this is different with a recent study by Riyanto and Mardiansjah (2018) which show the fisheries processing business actors in Pati Regency developed cooperation in the form of partnership such as procurement of processing supporting materials, procurement of raw fish, access to capital, and access to marketing of processed fishery products.

The relationship of each actor begins with the existence of a relief system in payment terms or capital provision to other actors, such as middlemen who provide relief to processors in the form of raw materials payment or debt in advance. After the fish is processed, then the retailer will sell the smoked fish. Retailers also receive payment relief from smoked fish processors, payments that can be made after the smoked fish have been sold in the market. In this case, a relationship with a high level of trust results in a shorter coordination system without prior written agreement. The coordination system shows the presence of key actors in a value chain. The main actors in the value chain of smoked fish products are processors. Smoked fish processors are referred to as the main actors in the value chain because they are very large compared to other actors, which consist of 76 groups, and each group consists of 3-5 people.

The most visible coordination system in the smoked fish value chain is when the buying and selling process takes place. Transactions are still carried out despite price changes between processors, middlemen, and retailers. The price changes does not have an impact on the coordination formed given the existence of a good trust relationship. The high level of trust has generated confidence among the three actors to be able to sell smoked fish products well. Technically, coordination activities in the smoked fish value chain are carried out only by using cellular phones, especially in order coordination.
Other actors in the smoked fish value chain are fishermen, wholesalers, food stalls, and restaurants. These actors also use cellular phone media in conducting their coordination systems. The coordination that occurs in some of these actors only covers ordinary trading transactions and there is no exclusive coordination such as the relationship between middlemen and processors or between processors and retailers. For example, when wholesalers do not get fish from one fisherman, wholesalers will easily buy fish from other fishermen. Likewise with food stalls when they do not get smoked fish from one retailer, then food stalls can buy from other retailers in the market. This condition is different from the relationship between middlemen and processors or between processors and retailers, where the relationship is more exclusive and based on family relationships.

However, relationships based on trust do not always run smoothly without obstacles. For example, delayed payments from processors will result in problems with chain effects. In this problem, the riskiest one are the middlemen. This is because payments from middlemen to wholesalers and fishermen usually have to be on time from the agreed schedule. Besides, problems also arise when retailers are late in making payments to processors, so processors will be late in paying to middlemen. This is because retailers get poor quality smoked fish, so they move to other processors. Likewise, with processors when they do not pay debts to middlemen for reasons of poor fish quality, so they move to other middlemen. However, this problem will usually be resolved and not last long because of the influence of long term relationship factors.

\section{Specific Regulations and Requirements in the Smoked Fish Value Chains}

Every actor in the value chain strives to deliver a quality product based on applicable regulations and certain requirements that must be met by each actor. Generally, each smoked fish value chain actor must understand good quality fish, such as having appropriate aroma, texture, and color characteristics. The fish used as a raw material must be fresh fish or frozen fish and have a bright color. Fresh fish has a texture that is not too soft and not hard, while frozen fish has a hard texture. Likewise, smoked fish produced by processors must pay attention to the aroma, texture, and color of good smoked fish as a determining factor for smoked fish 
quality. Smoked fish is said to be of good quality if it has a distinctive aroma of smoked fish, the texture of smoked fish is not too soft and not hard, and the color looks brownish-yellow.

Each actor must comply with regulations by their respective capacities. For example, fishermen who must obey the rules of fishing, such as not allowed to use explosives and must use environmentally friendly fishing equipment, then the wholesalers must use cold storage according to the standard so that the fish are kept frozen in the required degree. Furthermore, middlemen must use non-hazardous preservatives such as ice cubes, fiber containers, or refrigerated cars in the distribution process. At the processing level, smoked fish processing must be hygienic. The smoked fish processing environment must always be clean. After that, retailers must sell smoked fish products that are still fresh and odorless so that consumers get good quality smoked fish products.

In general, all value chain actors must comply with raw material requirements that must be free of chemicals and the processing must be standardized by the government requirements. The role of government is needed in monitoring the fulfillment of requirements or regulations that apply to each value chain actor. For example, the Department of Maritime Affairs and Fisheries of Demak Regency conducts routine supervision of the use of fish raw materials that are free from hazardous chemicals. In addition, there is also an inspection activity from the local government related to food safety of smoked fish products produced by taking and testing samples of smoked fish products that are safe for consumption.

\section{Control Mechanisms in the Smoked Fish Value Chains}

Dimensions of control mechanisms are part of governance related to the delivery of important information among actors in the value chain. The control mechanisms also deal with compliance with certain regulations or requirements that are in the value chain. The process to ensure that activities of each actor by applicable regulations will be controlled by parties outside the smoked fish value chain (government). For example, fishing activities must have a boat permit and use environmentally friendly equipment. In general, the control mechanism in the value chain is largely determined by the information factor. Control mechanisms in the smoked fish value chain, among others, are related to the payment process, raw material acquisition, and quality determination.

In the smoked fish value chain, the delivery of information moves between actors in a maze or asymmetric information. Information about a matter can be spread vertically and horizontally into more than one version whose truth has not been guaranteed, so actors usually dig or find information to various parties to convince and find the truth of the information circulating. Not infrequently, actors make decisions based on developing issues. This happens because no one party has a strong ability to hold control of information. However, information controls tend to be owned by processors because processors are the main actors in the value chain. Although in this case, the processor does not have more power to make decisions unilaterally because of the dependency relationship with other actors such as middlemen and retailers.

Regarding payment, one of the problems is related to the period of payment, which is product payments made within several days or debt. Processors in this condition have control to determine the period of payment. However, when it reaches the agreed time limit but the processor does not pay its debt to the middlemen, the next day the middlemen will not supply the fish to the processor. If the processor still does not make payments, then social sanctions will work. The processor will be blacklisted and the name of the processor will be spread to other actors. In this case, the solving problem is generally done by non-violent methods because of the relationships that have existed for a long time, hereditary, and mutual need.

In addition to dealing with payment rules, the control process is also carried out by each actor on several matters relating to information about the price and quality of fish or information about markets and other actors in the value chain. In this case, the control process tends to be in the hands of the main actor or the processor, even though the processor does not fully have a large control power. Processors can determine the criteria for the quality of raw materials they need from middlemen and determine which retailers are entitled to sell their smoked fish products. Problems occur, for example, when the processor wants to find a cheaper and more reliable supplier of raw materials, this is difficult 
to do because of the long term relationship with the middlemen. The flexibility of payment and the period of debt payment provided by the middlemen, making the processor feel indebted so that the collaboration with the middlemen who currently supplies raw materials will continue and not move to other middlemen.

\section{Types of the Smoked Fish Value Chain Governance}

Types of governance in the value chain are determined by three determinants, which consist of the complexity of the transaction (complexity), the ability to translate requirements in transactions (codify), and the ability of suppliers (capability). The combination of these three factors is used to determine the type of governance that is formed in the smoked fish product value chain (Figure 3). Based on these three determinants, the smoked fish value chain is included in relational governance that has high transaction complexity criteria, ability to translate requirements in low transactions, high supplier capability, explicit degree of coordination, and moderate power asymmetry.

Smoked fish value chains have complex transactions (high complexity), which are the characteristics of the purchase of raw fish and smoked fish products on a large scale. The specifications of fish raw materials that are good for processing into smoked fish are only a few types of fish including manyung, tongkol, and pari.

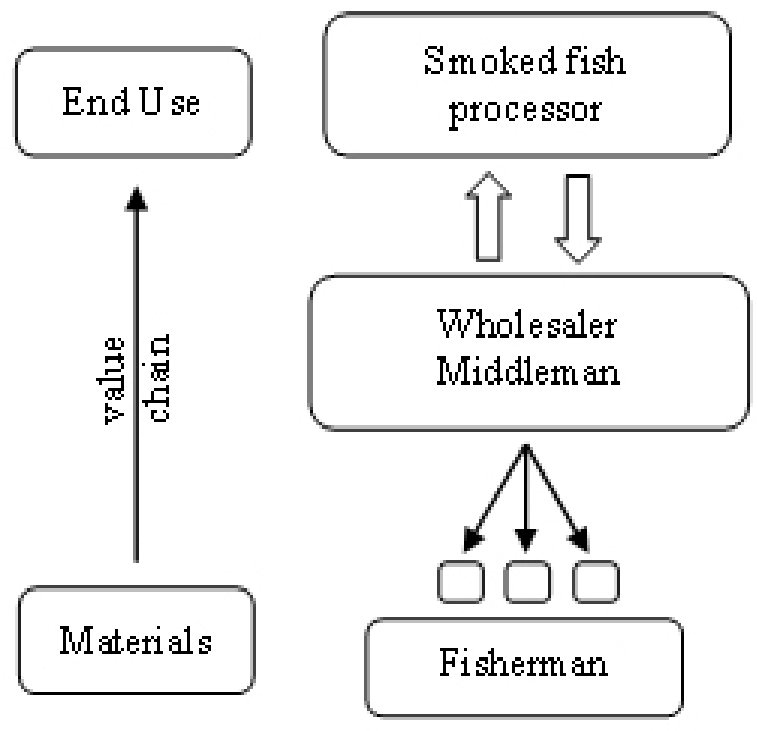

Figure 3. Type of relational governance of smoked fish value chains in Demak
Besides, the smoked fish value chain has product specifications that are relatively not easily codified (low codify), which is characterized by the collaborative process of each actor carried out informally or without the existence of a written agreement document, for example in the activities of ordering raw materials for fish or smoked fish products, it is not through a written agreement, but ordering is done directly using communication media by telephone or text message.

The ability of suppliers to provide raw materials in the smoked fish value chain is relatively high (high capability). This is demonstrated by the ability of middlemen who always send fish raw materials routinely and on time. Likewise, smoked fish processors always produce smoked fish products by retailer orders.

Each smoked fish value chain actor is also interdependent. This condition is seen when fishermen cannot go to sea, the supply of raw materials will be disrupted and will reduce the amount of smoked fish that can be sold in the market. Information circulating in the smoked fish value chain tends to be limited among actors and not widely spread. Information circulates in various versions and spreads secretly so that the actors must collect information from various parties to avoid the asymmetric information.

\section{Managerial Implications}

Based on the analysis of the governance of the smoked fish value chains, it was found that the governance was still in the informal form. Therefore, it is necessary to increase the role and strengthening of institutions through cooperatives that are formed at the smoked fish center (KUB Asap Indah) as an institution that coordinates processors as the main actors in the value chain. The institutional strengthening of cooperatives is aimed at making the smoked fish value chain governance better so that the coordination and relationships created between value chain actors can be established formally and written. Thus, it will be able to provide greater benefits for each actor involved in product creation in the value chain and to be able to minimize the occurrence of asymmetric information, especially related to price, product quality, and availability of goods. Besides, strengthening the role of the institution is needed as the main institution for collaborating with various parties as an effort to expand product sales and increase product competitiveness. 


\section{CONCLUSIONS AND RECOMMENDATIONS}

\section{Conclusions}

Governance in the smoked fish value chains in the North Coast of Central Java is categorized as the relational governance with high complexity, low codify, and high capability. This is indicated by the existence of informal cooperative relations without written agreements and using conventional means of communication. Each actor must meet certain regulations and requirements to produce good quality of the smoked fish products for consumers. The transactions carried out in the smoked fish value chain are complex and interdependent, product specifications are not easily codified, and high supplier capabilities are required. Each value chain actor must gather information from various parties to obtain valid information and minimize the occurrence of asymmetric information.

\section{Recommendations}

The development of sustainable smoked fish value chains in the North Coast of Central Java needs support from every actor involved along the chain by making a formal and written cooperative relationship. Thus, coordination between actors in the value chain can work well. In addition, formal and written cooperation can also maintain price stability and goods availability based on mutual agreement. In addition, the role of local government as a mediator is needed to support the creation of a formal relationship between every smoked fish value chain actor.

\section{REFERENCES}

[ACIAR] Australian Centre for International Agricultural Research. 2012. Membuat Rantai Nilai Lebih Berpihak Pada Kaum Miskin: Buku Pegangan Bagi Praktisi Analisis Rantai Nilai. Canbera: ACIAR Monograph No. 148.

[KKP] Kementerian Kelautan dan Perikanan Republik Indonesia. 2018. Produktivitas perikanan Indonesia. https://kkp.go.id/wp-content/ uploads/2018/01/KKP-Dirjen-PDSPKP-FMBKominfo-19-Januari-2018.pdf [21 Jan 2020]

[KKP] Kementerian Kelautan dan Perikanan Republik Indonesia. 2019. Kelautan dan perikanan dalam angka tahun 2018. http://sidatik.kkp.go.id/files/ src/023dfaa957829d846cfb59164b6c5774.pdf
[22 Oct 2019]

Ahmad T, Daryanto A, Oktaviani R, Priyarsono DS. 2018. Global value chain of Indonesian pulp and paper industry. Jurnal Manajemen dan Agribisnis 15(2):118-128.

Albuloushi N. 2018. Governance configurations: testing the global value chain framework [dissertation]. Australia: Queensland University of Technology.

Alhassan EH. 2012. Smoked and frozen fish consumption and marketing channels in the Tamale Metropolis of Ghana. Ghana Journal of Development Studies 9(1):21-28.

Arsiwi P, Adi PW, Subhiyakto ER. 2018. Analisis value chain sebagai upaya peningkatan nilai produk ikan asap Bandarharjo Kota Semarang. Industrial Engineering Journal of The University of Sarjanawiyata Tamansiswa 2(1):35-43.

Clay PM, Feeney R. 2019. Analyzing agribusiness value chains: a literature review. International Food and Agribusiness Management Review 22(1):3146. https://doi.org/10.22434/IFAMR2018.0089

Dzaki A, Sugiri A. 2015. Kajian eksternalitas industri pengasapan ikan di Kelurahan Bandarharjo Kecamatan Semarang Utara. Jurnal Teknik PWK 4(1):134-144.

Gereffi G, Humphrey J, Sturgeon T. 2005. The governance of global value chains. Review of International Political Economy 12(1):78-104. https://doi.org/10.1080/09692290500049805

Hastings K, Howieson J, Lawley M. 2016. Creating value chains: the role of relationship development. British Food Journal 118(6):1384-1406. https:// doi.org/10.1108/BFJ-10-2015-0389

Hellin J, Meijer M. 2006. Guidelines for value chain analysis. Food and Agricultural Organization of the United Nations. http://www.fao.org/ fileadmin/templates/esa/LISFAME/Documents/ Ecuador/value_chain_methodology_EN.pdf [15 Dec 2019]

Kaplinsky R, Morris M. 2002. A handbook for value chain research. https://researchgate.net/ publication/42791981_A_Handbook_Value Chain_Research [1 Nov 2019]

Kotni DP. 2016. Value chain management in marine fisheries: a case study of Andhra Pradesh. International Journal of Managing Value and Supply Chains 7(2):9-19.

Mishra PK, Dey K. 2018. Governance of agricultural value chains: coordination, control, and safeguarding. Journal of Rural Studies 
64(October):135-147. https://doi.org/10.1016/j. jrurstud.2018.09.020

Puspito DP, Kusnandar, Setyowati N. 2016. Analisis rantai nilai ubi kayu di Kabupaten Pati. Journal of Sustainable Agriculture 31(2):94-101.

Riyanto S, Mardiansjah FH. 2018. Kajian pengembangan industri pengolahan perikanan dalam pengembangan ekonomi lokal di Kabupaten Pati. Jurnal Pembangunan Wilayah dan Kota 4(1):61-71.

Rosales RM, Pomeroy R, Calabio IJ, Batong M, Cedo K, Escara N, Facunla V, Gulayan A, Narvadez M, Sarahadil M, Sobrevega MA. 2017. Value chain analysis and small-scale fisheries management. Marine Policy 83(May):11-21. https://doi. org/10.1016/j.marpol.2017.05.023

Sugiyono. 2014. Metode Penelitian Pendidikan Pendekatan Kuantitatif dan Kualitatif, dan $R \& D$. Bandung: Alfabeta.

Swastawati F, Cahyono B, Setiono I, Kurniasih RA. 2017. Penguatan usaha pengasapan ikan "KUB Asap Indah" Desa Wonosari Kecamatan Bonang Kabupaten Demak dengan teknologi pengemasan vakum. Jurnal Info 19(1):34-45.

Theuri FS, Mwirigi FM, Namusonge G. 2014. Determinants of value addition in the seafood industry in developing countries: an analysis of the Kenyan Context. Journal of Business and Management 16(1):17-25.

Trienekens, JH. 2011. Agricultural value chains in developing countries a framework for analysis. International Food and Agribusiness Management Review 14(2):51-82.

Yulisti M, Triyanti R. 2012. Peran kelembagaan dalam mendukung program minapolitan budidaya di Kabupaten Sleman, D.I. Yogyakarta. Buletin Riset Sosek Kelautan dan Perikanan 7(1):2733.

Yusri D, Daryanto A, Purwadaria H K. 2012. The study of botanical garden ecotourism value chain. Jurnal Manajemen dan Agribisnis 9(edisi khusus):19-25.

Yusuf D, Amiluddin A, Jumraini J. 2014. Peranan koperasi sebagai penyedia kebutuhan nelayan di Kabupaten Barru. Jurnal IPTEKS Pemanfaatan Sumberdaya Perikanan 1(2):174-184. 